\title{
En statsfanges papirer
}

Af fhv. seniorforsker, cand.mag. Harald Ilsøe

Efter afslutningen af den store nordiske krig blev der 1721 nedsat en dansk-svensk kommission, som skulle afgøre gensidige klager og fordringer fra borgere, der mente sig uretmæssigt ramt af krigen. Blandt de svenske forhandlere var friherre, generalmajor Gustav Wilhelm Coyet, som også havde personlige interesser at varetage, da danskerne 1710 havde plyndret familiens herregård Lyngbygård (nu Trolle-Ljungby) med et stort bibliotek og et righoldigt familie- og godsarkiv. Det lykkedes ham dog hverken at få de plyndrede ejendele tilbage eller opnå en pekuniær erstatning for tabet, hvis værdi han opgjorde til 20.000 rigsdaler. Misfornøjet hermed slog han sig efter kommissionens ophør ned i København for at gå videre med sagen, men lod sig friste til at deltage i konspiratoriske planer mod den danske krone. Da hans medvirken blev afsløret, dømtes han til døden, blev benådet med livsvarigt fængsel og fik den triste skæbne at sidde som fange i Kastellet fra 1723 til sin død 1730.

I kastellets arrest har der siddet mere kendte statsfanger, før Coyet den svenske nationalhelt general Stenbock og samtidig med og efter Coyet den engelske fribytter John Norcross, der på grund af flugtforsøg blev indespærret i et specielt fremstillet bur uden af den grund at tabe modet. Han underholdt sig med at dressere fængselsmusene og vakte med sit musemenageri så stor opsigt, at han blev forevist som en af hovedstadens seværdigheder i de femten år, han sad i buret. Fængselsophold udgør sjældent en opløftende historie, men handler undertiden også om ukuelighed. Det gælder kun i nogen grad Coyet.

Coyet var af profession officer, men et uroligt gemyt og noget af en eventyrer, der flere gange rodede sig ind $\mathrm{i}$ situationer, han ikke magtede at håndtere. Han var 
udmærket begavet og havde fået en adelsmands brede uddannelse, der indbefattede indlæring af sprogene latin, tysk og fransk og en længere udenlandsrejse til bl.a. Tyskland og Frankrig. Litterære interesser gjorde ham til en bogkyndig mand med et glimrende bibliotek i hjemmet i Stockholm, og da han blev indespærret, valgte han meget nærliggende at fordrive tiden med læsning og excerpering af bøger, som han reflekterede over og kommenterede i skriftlige optegnelser.

Fængselstilværelsen var ellers kummerlig nok. Den ene rigsdaler om dagen, som kongen havde bevilget til hans underhold, forslog ikke meget, og da han åbenbart forsøgte at komme i forbindelse med omverdenen eller måske havde gjort anstalter til et flugtforsøg, blev vinduerne i fængselsværelset muret til i april 1727. Han formåede nu ikke at holde modet oppe ret meget længere, slog sig på flasken og skal være død af druk sidst på året 1730. Derefter fulgte den 29. marts 1731 en auktion i Kastellet over hans ejendele, ifølge den trykte auktionskatalog bestående af et sparsomt fængelsmøblement, diverse service, tøj og bøger, alt i beskeden forfatning, så nettoprovenuet af salget kun blev sølle 12 rigsdaler 5 mark og 9 skilling. Blandt de mest værdifulde ejendele turde have været et egetræsskab, en sølvske og en kuffert betrukket med sælskind. Genstande som en paryk og ni gamle nathuebetræk (9 alte überzuge zu schlafmutzen) kan ikke have virket fristende på køberne, og næppe heller mere end et par af titlerne på de 25 bøger, som udgjorde hans brogede bogsamling. Nogle af dem havde han fået lov til at tage med i fængslet, andre må være erhvervet i fængselstiden som f.eks. en katalog over bøger, der var til salg på bogmessen i Leipzig 1726, og fra samme år auktionskatalogen over Fr. Rostgaards store bogsamling.

Coyets efterladte papirer derimod, koncepter til en række klage- og bønskrivelser samt hans optegnelseshefter, blev beslaglagt af staten og er omend ufuldstændigt havnet i Det kongelige Bibliotek. Hovedparten stammer fra Christian VIs statsminister Johan Ludvig Holstein, hvis arkiv og håndskriftsamling udgør en vigtig del af den sakaldte Ledreborgske Håndskriftsamling, og Holstein havde atter fået overladt dem fra historikeren Andreas Hojers bo (d. 1739). I sin fængselsisolation havde Coyet ingen grund til at forsyne optegnelserne med ejernavn, men ved beslaglæggelsen blev der affattet en fortegnelse over dem, nu ligeledes i Ledreborgsamlingen, og takket være den er det muligt så nogenlunde at rekonstruere, hvad der spredt er bevaret af hans efterladenskaber, ialt 18 håndskriftnumre (se fortegnelsen nedenfor). 
28 ein par prinbimetalf hembstrinufe

29 ein par itw warke ithuidtiaflen

30 ein jomarblacten fleid, to fe camijol uno hojen, wit dagrin gefittert

3I ein rother charlaquer mantel mit ermel/guidenen - Enopfen uno Enopflodien

32 ein fammfutter mit itroh geflodten

33 ein futh

34 ein par weibe hanbiduh

35 ein par (idul)

36 ein paruque

37 ein par îtuarke feidene frumpf alt

38 fteben feine obertetinboj

39. Drev' unter Dito

40 ein neffelouben bुatsoü

419 alte uberjuge $j u$ idslafmúthen

42 II alke.j申uf itider

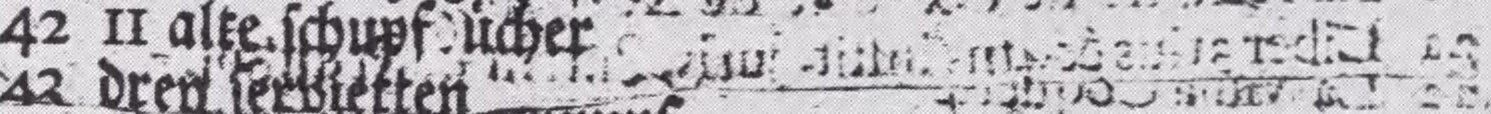

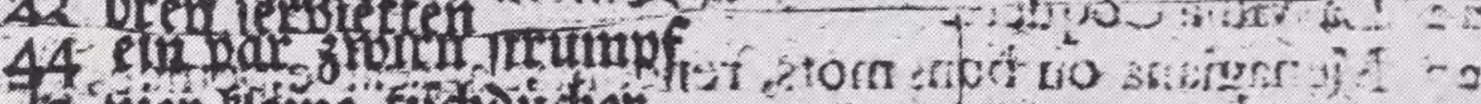

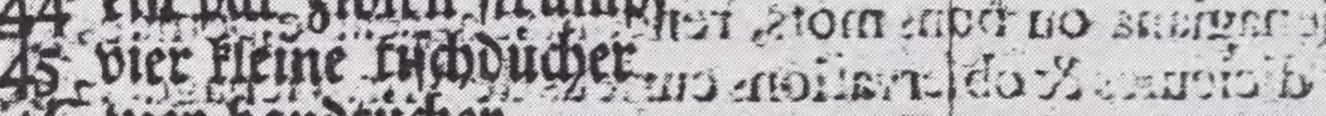

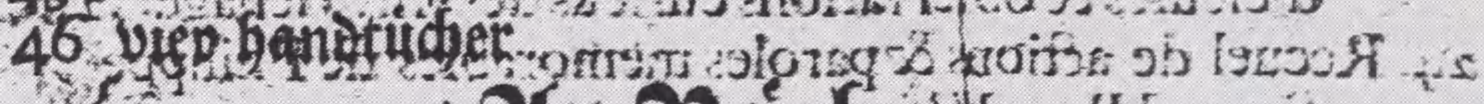

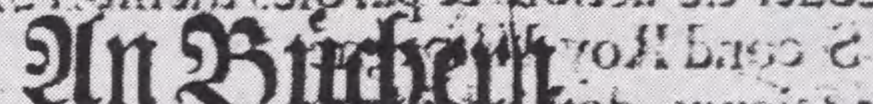

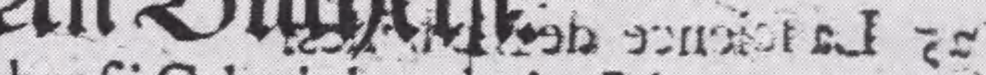

- Dictionarium Ambrofii Calepini, undecim Linguar. in foll.

2 (Fine teutiche Dolliighe $B$ ibel

3 Bejarefoung uber das sonigrted anan in

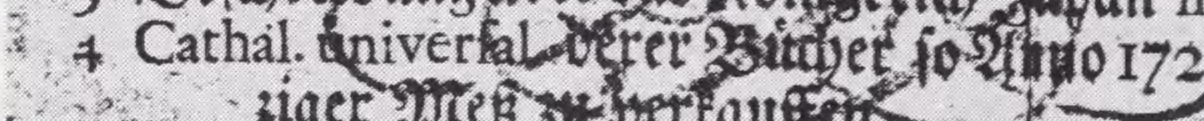

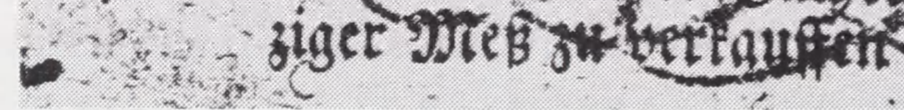

Fra auktionskatalogen over Coyets fængelsefterladenskaber.

Det er i sig selv mærkværdigt, at så meget er bevaret, og det skyldes nok, at optegnelserne ikke alene på underholdende vis afspejler en belæst og velformuleret adelsmands horisont i overgangsperioden mellem barok og oplysningstid, men også indeholder oplysninger af selvbiografisk karakter om en mand, hvis liv og slægt har sat sig spor i Sveriges og Danmarks historie. I Svenskt biografiskt lexikon er der artikler om såvel ham som broderen Sten, faderen Wilhelm Julius og farfaderen Peter Julius. Sidstnævnte var svensk forhandler ved den i Danmark berygtede Roskildefred i 1658, Wilhelm Julius var svensk gesandt i København i begyndelsen af 1680erne, 
og Gustav Wilhelm opskræmte altså den danske regering med statsfjendtlige planer, iøvrigt rene fantasiprojekter der bl.a. gik ud på at overdrage Grønland til Rusland.

Coyets optegnelser har så vidt vides ikke noget dansk sidestykke, og ud fra en formening om at de har en vis tidshistorisk interesse, præsenteres de her med nogle prøver på indholdet.

\section{Optegnelserne}

Nogle optegnelser om Holbergs forfatterskab har tidligere været fremdraget og findes gengivet i oversættelse til dansk i Edda XXIX, 1929, s. 106-12. Om dette har han mange lovord. Han har leet hjerteligt over Peder Paars og finder, at „Det danske Sprog har desuden i Comiquen og Satiren noget frem for alle andre Sprog i Verden med Undtagelse af det hollandske og ceteris paribus det franske“. Da han var på fri fod, forsømte han sjældent at se komedierne, skriver han, og „efter min Arrestation har jeg læst en stor Del af disse Stykker trykte, og jeg maa bekende, at mens de fleste Comedier mister noget af deres force, naar de læses, saa har disse næsten beholdt, om ikke forøget, hele deres Kraft".

Videre gør han rede for indholdet af komedieudgaven trykt 1723-25, hvor han så at sige på professionens vegne fandt satiren over den stortalende soldat i Jacob von Thyboe noget overdrevet, mens bl.a. Ulysses af Ithacia făr anerkendende ord på grund af satirens træfsikkerhed. Også Holbergs Metamorphosis, der udkom 1726, omtales, og da ingen af Holbergs skrifter, lige så lidt som de fleste andre af de kommenterede bøger, fandtes blandt hans efterladenskaber, må han i vid udstrækning have lånt sig frem. Hos hvem er ikke godt at vide, men det har vel været hos vagthavende officerer eller en besøgende præst. Et par steder nævnes det, at han fik denne eller hin bog „at se“, hvad der må betyde, at en besøgende med officiel adgang til fængslet har taget dem med for at vise dem til den boghungrende fange. Af mulige præster kan peges på „den redelige Guds Mannen Hr. Mag. Schreiber, Pastor wid tydska Kircken i Köpenhamn“, der omtales som udgiver af en salmebog udgivet til brug for den tyske menighed i København. Matthias Schreiber var ikke blot kendt for sit fromme og redelige sindelag, men også for at være ejer af et velforsynet bibliotek.

Intet emne har været Coyet fremmed, og han kommenterer lige så gerne bibel-

udgaver, grammatikker og astronomiske håndbøger som han refererer historiske og moralfilosofiske skrifter. Optegnelserne følger et vist system, idet de enten består af 
betragtninger om et emne angivet af en stikord eller knytter sig til henholdsvis et forfatternavn eller en bestemt bogudgave, sidstnævnte undertiden vurderet ved sammenligninger med andre udgaver, som Coyet husker han har haft hjemme i sit bibliotek. Under gennembladring af den Rostgaardske auktionskatalog slog han f.eks. ned på de såkaldte republikker, en hollandsk serie af små latinske landebeskrivelser, og sammenligner Rostgaards række med sin egen. Konklusionen er, at han af Rostgaards 47 udgaver selv har ejet de 44 .

Sit bibliotek mindes han også under stikordet Ana - og skulle læseren nu ligne en spørgsmålstegn, er han ikke den første, der gør det. Det viser sig, at 'ana' er en af franske boglærde lanceret betegnelse for bøger, hvis titel ender på denne stavelse, som regel et udvalg af en enkelt persons småskrifter og breve eller diverse mindre skriftstykker vedrørende hans biografi. Coyet kommenterer: „Det war en tid mode uthi den lärda werlden at göra små böcker eller samblingar af lärde och berömbde Mäns förlorne Papper och Skriffter. De äro rolige at läsa, och man finner i de mästa af dem mycken lärdom, Curiositet och Artighet. Man kallar dem Les Livres in ana, emedan de terminera sin Autoris namn på disse 3 Bokstafwer. Jag har uthi mit förre Bibliotheque ägt fölliande Ana“. Hvorpå han opregner en række titler, Casauboniana, Menagiana, Scaligerana etc., og sluttelig henviser til en Recueil choisi de tous les livres in Ana, med tilføjelsen: „Men denna recueilhade kunnat wara bättre, om des författare hade hafft bättre judicium".

For så at tage et konkret eksempel har Coyet excerperet og givet sin vurdering af en ana-samling fra 1696 med titlen Fureteriana ou les bons mots de Mr. Furetière (kendt fransk ordbogsforfatter og litterat). Efter et uddrag på 28 sider får den følgende skudsmål vendt mod de lærde smagsdommere: „Mig är nogsamt bekant, at ibland alla de små böker som ändas uppå ana, denna ibland de lärde passerar för den ringaste, och at man jämwäl påstår, det abbé Furetière däruthi icke hafft någon dehl. Men alt detta förhindrar mig ändå intet at döma om Fureterianis något mildare. Man finner wähl där intet rät många curiosa quoad rem literariam [hvad angår litteraturhistorien], ey heller bör man där söka några rara anecdota in politicis, men däremot kan man där med nöye läsa åtskillige artige bons mots, wackra smärre och större vers, rolige avanturer, och desföruthan många härlige moralier och andre erudite små passager, så at jag aldes håller före, det Fureteriana så mycket som alla de öfrige förtiänar at läsas och köpas“. 
Hvad grammatikker angår, dengang en betegnelse for sprogvejledninger i vid forstand, tildeles der Pepliers kendte og meget benyttede fransk-tyske grammatik både ros og ris. Eksemplaret, Coyet havde for hånden, var den 26. udgave i et Leipziger-tryk fra 1723, men i 1726 fik han Berlinerudgaven at se fra 1716, og ,jag fant denne långt angenämare och correctare än den Leipzische Editionen. Papperet är bättre och Tryck-Stijlen deslikes“. Han noterer med tilfredshed, at man i begge udgaver finder nyttige oplysninger om de korrekte titler i tiltale, en sand plage når man skulle iagttage de rette omgangsformer uden at dumme sig. Der er f.eks. mange titler at huske, når man færdes ved det brandenburgske hof, konstaterer han, men det foregår „doch icke på et så förbannat rasande och ridicult manér, som wid det kongl. Polska och Chur-Sachsiska hofwet“. Men tyskerne er i det hele taget glade for titler: „Man kan ... intet uthan löya observera, huru liberal Tysken är på Excellence Titelen. C'est tout comme icy, sade Docteuren till Arlequin, när han war Empereur de la Lune [Det er ganske som her, sagde doktoren til Harlekin, da han var kejser af månen]. NB. Jag ähr nu i Dannemarck“. Danskerne går altså ikke ram forbi.

Praktisk brugbar finder han også en fransk sproglære på tysk ved Joh. Jacob Sturm (Coburg 1710). Herfra refereres en anekdote for at illustrere, hvad ukyndig brug af en ordbog kan føre til: En ikke alt for begavet franskmand skulle finde ud af, hvad „Weihnachtsgedicht" hed på fransk. I et leksikon fandt han, at "Gedicht" på fransk kunne hedde „fiction“, og at „Weihnacht" var „la naissance de Jesus Christ“. Følgelig oversatte han "juledigt“ til La fiction de la Naissance de Jesus Christ! Personligt havde Coyet gjort iagttagelsen, at de fleste tyskere har svært ved at udtale fransk på korrekt måde. „Jag weet mig hafwa känt en Cavallier (en Niedersachser födt i Bremen), som uthi grund förstod det fransöska Språket, och jämwähl kunde skrifwa et godt bref, men då han talte med mig, förstod jag det i början så litet som hade det warit Mesopotamiska“. Og som Coyet med andre Holberglæsere jo ved fra Ulysses af Ithacia er specielt det mesopotamiske sprog et underligt sprog.

Inden for gebetet moral og praktisk filosofi er der gjort adskillige optegnelser, hvorfra blot skal anføres, at Coyet satte megen pris på Sylvestre du Four's Instruction morale d'un père a son fils (1678 og senere), og at han under stikordet Munera publica (offentlige embeder) opregner fem måder at komme frem i verden på. Med dem ser verden temmelig ussel ud: „Man har ordinarie fem Manér i werlden at poussera sin lycka med. Det första borde wara Capacitet och Skickelighet, men, 


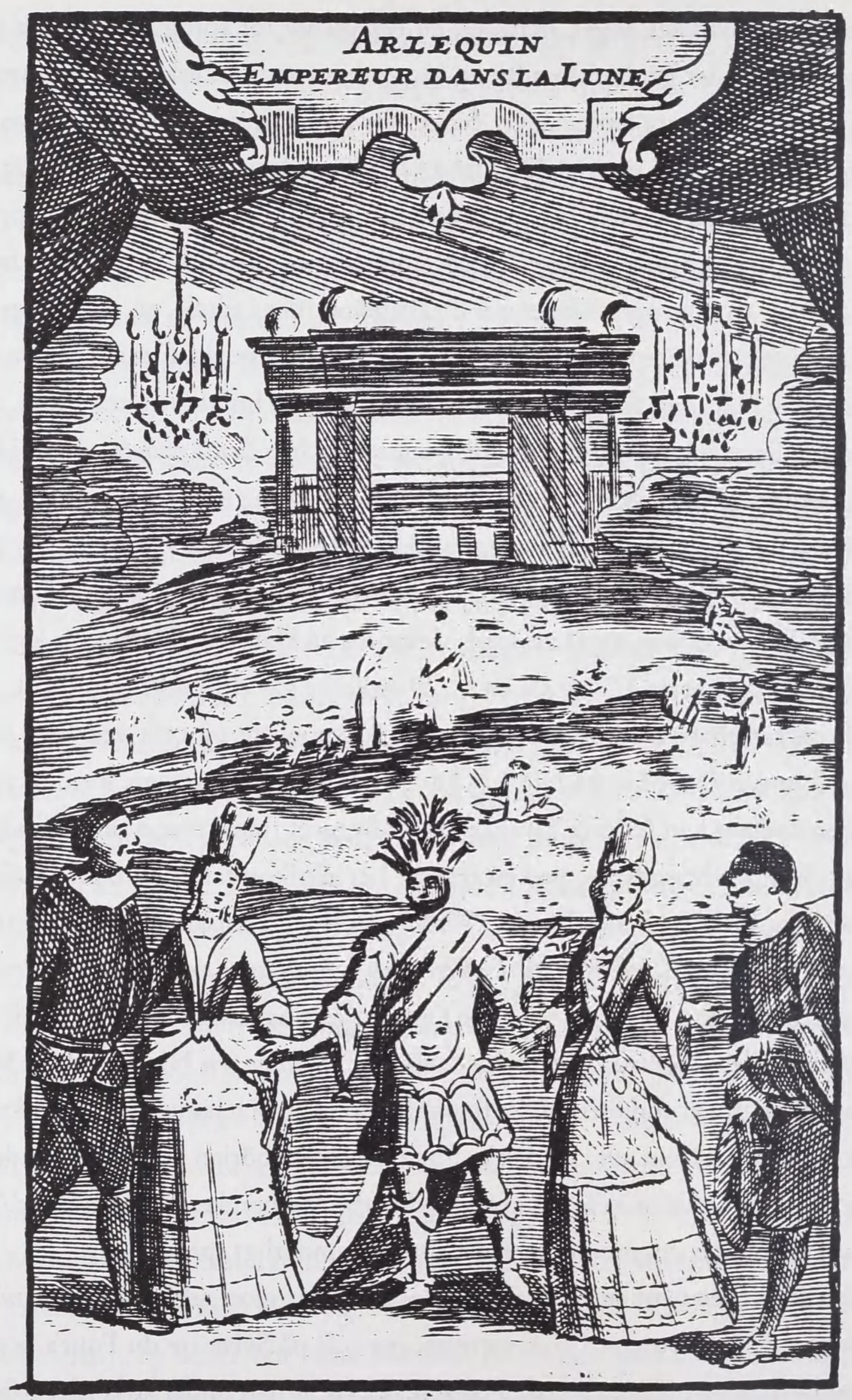

C'est tout comme icy siger Coyet med doktoren i en Harlekin-komedie og citerer dermed efter hukommelsen en replikpointe fra sidste scene af commedia dell'arte-stykket Arlequin Empereur dans la Lune. Teksten foreligger trykt fra ca. $1700 \mathrm{i}$ udgaver af samlingen Le Théatre italien de Gherardi, og illustrationen er hentet fra Amsterdam-udgaven 1721, bind I. 
dywärr, den står som oftast och mehrendels tilbakars. Det andra är hög börd och naissance. Det 3 die äro Patroner och förnäma förwanter, som sittia i Credit och wid Affairerne. Det 4 de äro Penningar, Mutor och Skänker [bestikkelser og gaver]. Det femte, som nu omstunder fast mäst brukas, är at man till Herrens eller Ministerns plaisir opofrar antingen sin sköna hustru, dotter, syster eller Cousine“.

Det var bl.a. lidt om værdien af kvindeskønhed i handel og vandel. Andetsteds har stikordet Mulieres (kvinder) givet anledning til et par betragtninger over det på Coyets tid debatterede fænomen femmes savantes - den stigende fremkomst af bogligt dannede eller lærde kvinder. „Det är wäl wist, at ingen homme de bon goust [mand af god smag] estimerer stort les femmes savantes, och det räknas med skähl för os ridicule [med rette latterligt] hos dem, när de praetendera at wara lärda. Men så behöfs intet, at de just skola wara aldeles ignorante och aldrig den ringaste teinture [anstrøg] hafwa af Grammatica, styl och Zijrlighet i tahl och bref". Coyet var forsåvidt moderat konservativ, og han undlader ikke at oplyse, at det for halvtreds år siden ligefrem regnedes for en skam, hvis en dame af stand røbede viden om grammatisk terminologi. Han gengiver anekdoten om en fransk dame, som engang blamerede sig i det gode selskab ved i en samtale at bruge ordet „vokaler“ (voyelles). Ah Madame, råbte de øvrige tilstedeværende damer, ved De virkelig, hvad vokaler er? - Fra selskabslivet i Stockholm husker han et par (desværre ikke konkretiserede) episoder, hvor der hændte noget lignende.

Bemærkninger om kærlighed og ægteskab gemmer sig blandt excerpter fra bøger om naturret. Man kan undre sig over, hvem der har givet ham en så ejendommelig bog i hænde som Traité de Eunuques, udgivet i Paris 1707 under pseudonymet Ollincan, men bogens placering i konteksten er rimelig nok, når der lægges vægt på emnets juridiske aspekter - kan det f.eks. tillades eunukker og impotente at gifte sig? Den har åbenbart også behandlet forholdet mellem de to køn i almindelighed, og Coyet uddrager heraf den borgerlige betragtning, at „man kan ochså i sit äktenskaap förgåa sig och fördärwa sin hustru par trop d'amour. Så ähr det ey heller rådeligt at giffta sig med en Person, uthi hwilken man är dödeligen kär“. [I margin:] „Uthi äktenskapet bör man ärbarligen och förnufteligen lefwa“. Senere er han kommet i tanke om, hvad en officerskollega har sagt om ægtestanden, og tilføjer så: „NB. Hr. Generalmajor Donop plägade altid säga, att de första äktenskapsåhren lefde mann och hustru med hwarandra som horor och bofvar [skøger og horkarle], 
då hwarken bord, stohlar, wägg eller bänkar förskontes. Sedan lefde de tilsammans några åhr som mann och hustru med ärbarhet och måtelighet. På sidstone omgiks de som Broder och Syster. Ähr både artigt och sant sagt“.

Som læser af filosofiske skrifter er han svoren beundrer af de to samtidige tyske filosoffer Christian Thomasius og Christian Wolff. Om Thomasius hedder det, at „Alt hvad Hr. Thomasius skrifwer är angenämt at läsa, och hans goda skarpsinnige Judicium framlyser öfwer alt. Hans satyriske spitze stijlen förorsakar det förra, och det senare bör tilskrifwas hans solide Erudition och idelige Meditationibus". Men Wolffs forfatterskab sættes ikke mindre højt, „ty jag wet mig aldrig någon in physicis \& mathematicis hafwa skrifwit med mehra förnufft och sannlijkhet än han, ey heller in metaphysicis [vedr. erkendelsen af det uhåndgribelige] med mehra tydelighet, då denne wetenskab likwähl är en utaf de aldramörkeste". Bøger af Wolff havde han kun til låns i nogle dage, men håber optimistisk at kunne erhverve dem selv. Efter læsningen af et af Wolffs mange skrifter, hvis titel begynder med Vernünftige Gedanken, skriver han: "Nu hade jag wäl tänkt at exerpera de förnämsta passager uthur denna härlige book, men som det willa falla mig alt för widlyfftigt och därmed mycken tid skulle förspillas, så håller jag bättre at effter handen anskaffa mig både denna och alle de öfriga autoris nyttige skriffter och ärnar då (will gud) in calce annotera notanda [notere, hvad der bør noteres, bag i bogen] effter mit wanlige bruk i egne böker".

Interesse for medicin og lægekunst spores i afskriften af en række recepter og et notat under stikordet Variole (kopper). Under overskriften „Något om Barne Kopper" advares mod følgerne af at beskytte børn mod at blive smittet af kopper. Det er langt bedre at få dem som lille end som voksen. Rammer sygdommen nemlig en som voksen, bliver man forfærdelig koparret eller dør simpelthen. Han taler af egen erfaring, for det oplyses som eksempel på det første, at han selv fik kopper i 20 årsalderen. Et eksempel på at de kostede livet er den svenske prinsesse Hedvig Sophia (f. 1681), som døde af kopper 1708. Han har kendt hende og mindes, at „hon föruthan de aldrahärligste Sinnets gåfvor ännu ägde en stor Kroppens skönhet“.

Ikke mindst i den religiøse litteratur forekommer Coyet velbevandret og udtaler sig frejdigt om kvaliteten af salmebøger, bibler, bibelkommentarer osv. F.eks. har han ikke meget til overs for den danske præst Georg Ursins fortolkning af Jobs bog, trykt 1726 og læst 1727, men som god kristen har han udset sig mindst een andagts- 
bog, han gerne søger trøst i. Foruden en tysk bibel ejede han i fængslet tre opbyggelige bøger, Johann Gerhards Sacro meditationes, Othfarii Geistlischer Hertzfasser und Seelenstiller og Lassenii Biblischer Weyrauch. Sidstnævnte omtales med varme: "Jag hembär den goda Barmhertige Guden en ödmiuk och hiärtelig taksägelse, at jag kort för min arrest hade köft denna sköna bönboken, hvaruthur jag icke liten tröst hämtat uti min bedröfwelse och med Nytta och glädie där funnit samblade de aldrahärligste Skriftens språåk“.

Johannes Lassenius var præst ved den tyske kirke i København 1676-92 og udgav en stribe andagtsbøger, som fik stor udbredelse i Danmark og Tyskland. Den mest populære var netop bønne- og salmebogen Biblischer Weyrauch - på dansk med den barokke titel: Bibelske Wirach til gudelige Andagters søde Lugt - så Coyet var ikke ene om at sætte pris på bogen. Men interessant er det jo, at han har sat sig ned og begrundet sin forkærlighed for den. Hans egen udgave var trykt i duodecformat hos Gleditsch i Leipzig 1717 (iøvrigt ikke registreret i Ehrencron-Müllers forfatterleksikon) og aldeles fortræffelig: „Denna Editionen är wähl den bäste af alla härtildags utkomne, skön, nitide, warandes dicta S. Scriptura sub quavi pagina allegerade [med angivelser af skriftens ord på hver side], och är altså bättre än den som Thomas Pritsch låtit uplägga i Leipzig in 8vo 1723“ (den har Ehrencron-Müller). Og videre: „Som Sahl. Hr. Doctor Lassenius uti sina böner allenast bunkat [har samlet] och anwändt den h[eliga] Skriffts egne Språck och Ord, altså hafwa de ochså långt mehra Klämm [fyndighed] och andakt med sig, röra därjämte et Guds barns hierta mehra än andra böner". Da indholdet dog forekommer ham noget ujævnt, må han tage det lille forbehold, at „så har den sahl. gode Mannen likwäl icke hafft lika andans drifft"! Af bønnerne bagest i bogen finder han navnlig bønnerne ved sygdom og død fulde af ånd, mens et salmebogstillæg ikke er af de mest fuldkomne, men dog tilstrækkeligt. En af manglerne har han udbedret på egen hånd: ,Jag har uthur den Stadiske Psalmboken af 1712 i mit Exemplar af Lassenio annoterat wid hwar och en Psalm Autoris Namn".

Tro og teologi udelukker ikke overtro, og han beskæftiger sig gerne med spådomme, forudsigelser o.lign. Han havde fået fat i en årligt udgivet publikation med astrologisk begrundede, men selvsagt passende dunkle forudsigelser af det kommende års politiske begivenheder. Englischer Wahrsager, hed den og kom i Coyets eksemplar med forudsigelser for året 1725. Han meddeler: „Jag har uppå inne- 
warande åhr 1725 sökt at giöra Autoris profetier tydeligare ... Har jag ibland fehlat, så ähr det icke mycket angeläget, al den stund jag uppå slika astrologiska gissningar icke stort bygger". Han afviser dem altså ikke helt og breder sig over flere sider med sine udtydninger, vel mest for at underholde sig selv, men sikkert også parat til at lade sig overbevise, hvis noget skulle komme til at passe. Heller ikke kan han stå for mærkelige sammentræf, der forekommer ved talberegninger af en type, som vel har eksisteret så længe som talbegrebet selv. Tag nu f.eks. Ludvig 14. af Frankrig. Han var født 1638 og døde 1715. Summen af de to første cifre i 1638 er 7 , af de to sidste 11. 7 gange $11=77$, og 1 ægges dette tal til 1638, fremkommer dødsåret $1715 ! \mathrm{Og}$ hokuspokus endnu en gang: Tværsummen af 1715 er 14 - og 14 er just kongens nummer i rækken af franske kong Ludvig'er!

Et helt livsperspektiv giver hans personlige udlægning af begrebet annus climactericus. Ligesom selv teologer og højtoplyste mænd frem til begyndelsen af 1700-tallet var Coyet offer for forestillingen, at visse leveår og levedage indebar alvorlige risici for liv og helbred. Det gjaldt for leveårenes vedkommende navnlig år, som var delelige med tallene syv eller ni, og af disse blev atter det 49. og 63. leveår, der jo udgør produkter af henholdsvis 7 gange 7 og 7 gange 9 år, anset for særlig farlige, dvs. som mere end mulige dødsår. Sådanne kritiske leveår kaldtes et annus climactericus, og apropos, hvad han havde læst herom, efterprøvede han denne regel om en skæbnebestemmende livscyclus ved at se tilbage på sit eget livsforløb (i det følgende oversat fra tysk). Det må forudskikkes, at han var født den 5. april 1678:

„Jeg vil af egen erfaring forbedre denne artikel de Annis Climactericis et Diebus criticis. Min salige hr. bedstefader døde i sit 49. år. Min salige hr. fader i sit 63. Min salige fru moder i sit 42. Jeg selv faldt i det 7. år ind under isen og blev med nød og næppe reddet. I det 9. måtte jeg udstå en farlig sygdom, som varede til det 14. I det 18. til 21. år blev jeg [på studierejse i udlandet] indblandet i lutter uheldige affærer og dueller, blev ofte selv såret og andre også. I det 27. og 28. år gik mig alting imod, jeg havde også i det 27. uheldet i Damgarten. I det 35. og 36. havde jeg udelukkende en ond tid. I det 40. mistede jeg min i denne verden i al evighed uforglemmelige konge [Karl XII, d. 1718]. I det 45. blev jeg [febr. 1723] arresteret i København, og i dette nuværende mit 49. år tror jeg ganske sikkert, jeg vil dø. Dette år [dvs. 1726/27] har været det værste, ubehageligste og usundeste i hele mit liv. Guds nådige vilje ske! Men skulle min Gud af hellige årsager lade mig passere det 49. år (nemlig d. 5. april 


$$
\begin{aligned}
& \text { Aularen Curspormem prosend thatus. }
\end{aligned}
$$

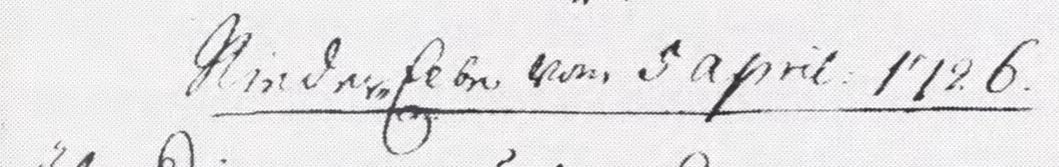

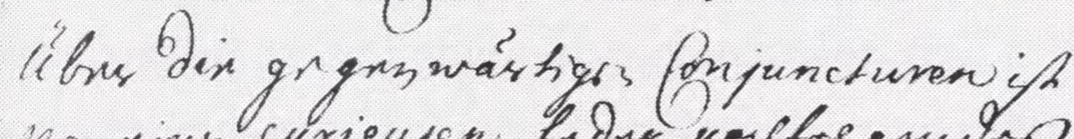

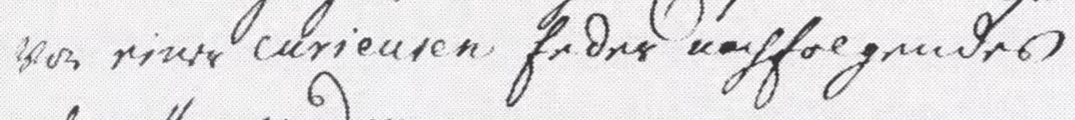

$$
\begin{aligned}
& \text { m.. biorftin wordere. }
\end{aligned}
$$

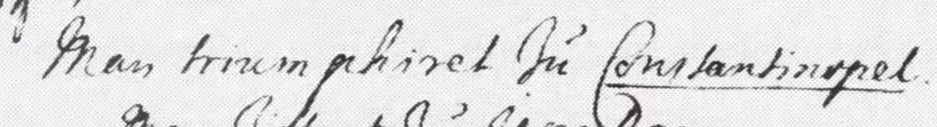

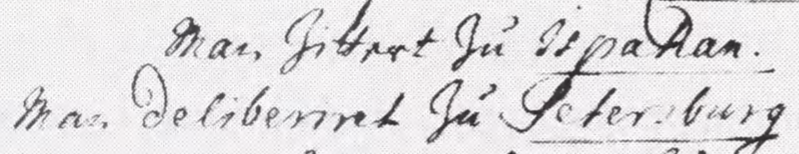

$$
\begin{aligned}
& \text { Bran, as britut ga' evien. }
\end{aligned}
$$

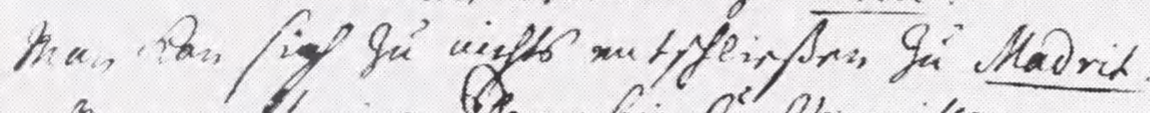

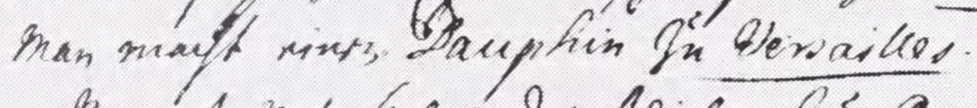

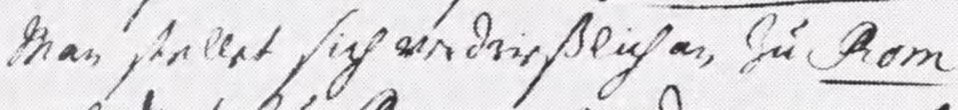

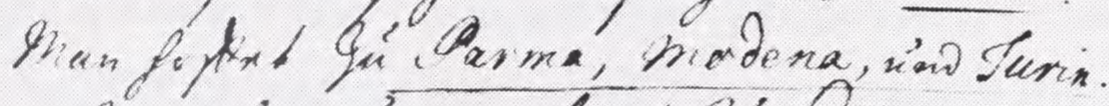

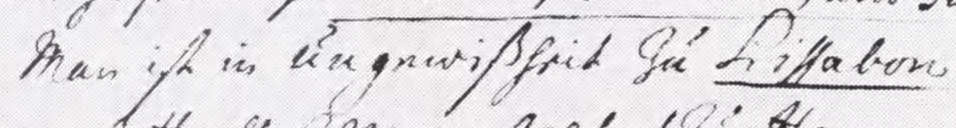

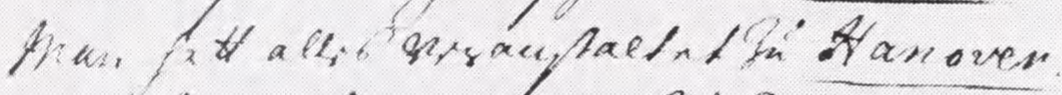

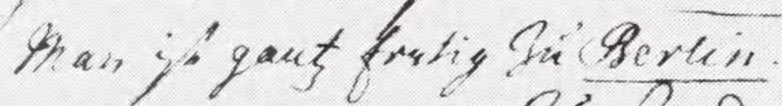

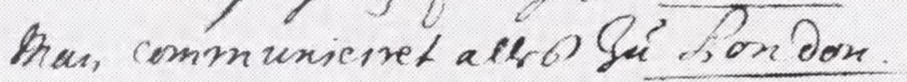

$$
\begin{aligned}
& \text { Than, avancired Gú Shrkholm. }
\end{aligned}
$$

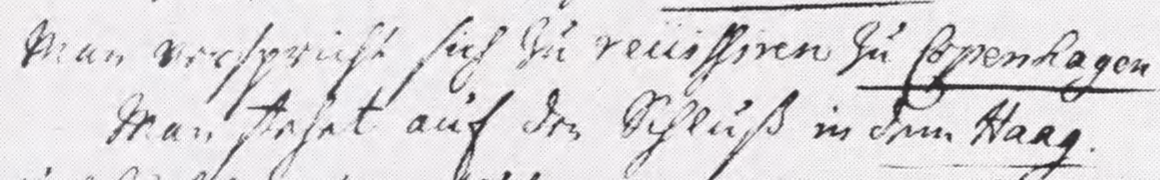

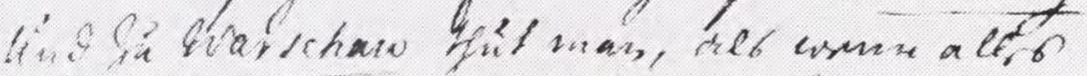

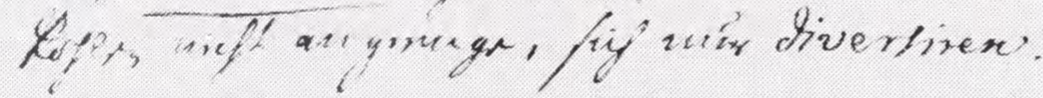


[på 49-årsfødselsdagen 1727]), så er jeg af den faste tro, at jeg endnu en gang af guddommelig nåde vil blive hjulpet og formodentlig dø i det 54.-56. eller 63. år“”

Spredte erindringsglimt er allerede citeret, og et par stykker kan føjes til. Efter en længere fristil om Karl X Gustavs liv og levned omtaler han dennes uægte søn, grev Gustav Carlsson (1647-1708), som gjorde et rigt giftermål og bosatte sig i Holland. Der havde Coyet truffet ham og fortæller: „Jag har hafft den ähra at känna gref Gustaff Carlson anno 1697 och 1700 i Holland. Han har bägge åhren, och medan jag wistades i Amsterdam, gifwit mig många sköna soupées, recommanderat mig mången wacker book, och jag har jämwähl fölgot honom 3 eller 4 gånger au bordelsamt med andra Swänska Cavallierer, då han altid ... förbehölt sig maquerellen [bordelmutter], effter hon war en gammal utlefwad käring". Fra et senere ophold i Leipzig husker han en pudsig episode ud for en italiensk vinkælder, hvor han i et ordskifte på italiensk råbte til kældersvenden, der stod ude på gaden „Hvad bestiller din herre“ - og fik det afslørende svar „Han er nede i kælderen og lave italiensk vin“. Men han har også mørke erindringer og ser opholdet i Leipzig under en helt anden synsvinkel i et stærkt religiøst farvet tilbageblik, hvor også uheldet i Damgarten (i Pommern) bliver forklaret. Tilbageblikket er foranlediget af læsningen af et sted i Jobs bog, som har berørt ham dybt. Det sted hvor det hedder: Se, saligt er det menneske, som Gud straffer; derfor skal du ikke foragte den Almægtiges tugtelse. Thi han gør smerte og forbinder; han gør sår, og hans hænder læger. I seks angster skal han fri dig, og i syv skal intet røre dig (Job 5.17-19). Coyet føler nu, at han efter sine prøvelser er nået til fase syv og priser sin gud for, at han uskadt er nået så langt. Han mindes to situationer:

„... först Anno 1704 den 3. Januarij, då jag olyckeligen och emot all min tancka och wållande kom at til dödz sticka en drucken Soldat i Damgarten, som mig uthi wärdzhuset, då jag nyligen war af Postwagnen afstigna, oförskämbt med skälsord, hugg och slag, uthan den ringaste giwen orsak, attaquerade. Alwetande Gud, dig är aldrabäst bekant, at jag emot denna olyckliga Mannen aldrig hafft något upsätt hwarken at förspilla hans Lif eller skada honom på något märkeligt sätt, men din hand war den timan emot honom, och du behagade bruka mig till et bedröfveligt Instrument af dina wrede och hämbd. Nu Herre, jag syndade och kan mig icke rätfärdig göra för dit aldraheligste Ansikte, oansedt jag eftter lag och bewiis af den wärdzlige domaren blef in totum frijkiänd. Du halpst mig uthur denna Nöden, 
effter jag dig bad, og du täktes med Nåde denna gången ansee mit Hiärtas oskyldighet i denna Mannens blod.

Jag kommer, mildeste Gud, för det andra ihog, huru nådeligen din högra hand beskärmade mig Anno 1707 i Leipzig, då jag nästan hwar dag war underkastat Dueller, slagsmåhl och fortretligheter. Mit wäsende war wähl den tiden aldeles icke rätskaffens emot dig, al den stund jag lefde uthi dagelige Synder, Svordom [banden og sværgen], Otukt, Spehl och Trätor. Doch halpst du mig Herre, at mig icke den ringeste Skada wederfors, ehuru wähl månge hade oplagt Råd emot mig at fordärfwa och skada mig. Det war dit wärck, min Gud, och du lockade mig till Bättring igenom din tålmodighet och Nåde“.

Den strenge isolation, som var følgen af tilmuringen af fængslet 1727 , blev dog en prøvelse, Coyet ikke i det lange løb kunne bære. De fleste af optegnelserne er dateret med angivelse af årstal. Hyppigst 1724-26, sjældnere 1727 og heraf atter nogle få med et „1727 efter at vinduerne var tilmuret“, men vistnok slet ingen fra de sidste fangeår. I 1728 tiggede han kommandanten om at få tilsendt aviser, men intet tyder på, at der blev vist ham synderlig imødekommenhed, og to år senere døde han mere eller mindre nedbrudt, 52 år gammel. Samtidshistorikeren Andreas Hojer mente at vide, at han indbildte sig at se ånder eller spøgelser og gav ham en ubarmhjertig nekrolog ved at fortælle, at han „als Liebhaber der Geister meist in dem geistreichen Getränke des Brantweins verzehrte, und sich dadurch gar bald das Leben, so Seine Majestät ihm geschenket hatte, selbst nahm“.

Måske var han en besværlig fange, men det liv, som Frederik IV skænkede ham, havde han ikke megen grund til at være taknemmelig for. Det var naturligvis også en følge af sær kongelig nåde, at liget blev transporteret til familiegravstedet i Skåne. Den svenske regering havde ad diplomatisk vej søgt at få hans sag genoptaget, men uden held, så det blev først ved modtagelsen af kisten i Helsingborg, de svenske myndigheder kunne demonstrere mod hans skæbne ved at salutere med 24 kanonskud.

\section{Efterladenskaberne}

Ovenstående hviler på en undersøgelse af, hvad der er bevaret af Coyets litterære og hidtil ufuldstændigt registrerede efterladenskaber i Det kongelige Bibliotek. Et vigtigt holdepunkt har været en fortegnelse, som myndighederne lod udarbejde efter Coyets død, nu i Ledreborg 269 fol. Med denne er så sammenstillet, hvad der har 
kunnet findes i bibliotekets håndskriftsamling bortset fra et par håndskrifter, som ikke står anført i fortegnelsen. En samling salmeafskrifter og -kommentarer i GkS $35218 v o$ er indgået i biblioteket senest 1730 og er muligvis blevet beslaglagt allerede ved Coyets fængsling 1723, og et andet håndskrift, der består af nogle få blade i Ledreborg 4544 to (med de citerede betragtninger over Jobs bog), er måske en afskrift og under alle omstændigheder løsrevet fra sin oprindelige sammenhæng. Det samme gælder en spådom på fransk om Sveriges forening med Danmark, en afskrift på kun tre blade i Ledreborg 253 4to, som statsminister Johan Ludvig Holstein, der havde Coyets efterladenskaber i sin varetægt, åbenbart havde studeret og sendte Christian VI til gennemsyn i 1742. Anledningen var den aktuelle udenrigspolitiske situation, der havde fremkaldt danske planer om at samle Danmark og Sverige i en personalunion. „Wir finden es couriös“, lød kongens dom, „wünschen wenn es Gottes Wille ist, dass die Prophezeiung möge erfüllet werden“.

Fortegnelsen i Ledreborg 269 fol. lyder med tilføjede håndskriftidentificeringer:

Extractus Protocolli Derer Jenigen Manuscriptorum, welche der Verstorbene General Major Cojet hinterlassen

1. Ein gewiss Project in folio, und Copien von verschiedenen Memorials und Briefen sub No. 1 [Rimeligvis $=1$ ) Ledreborg 76 fol. (koncept til Coyets tanker om en alliance mod Rusland dateret aug. 1723) og 2) Ledreborg 462 fol. („Copien von Coyets memorialen und briefen“, hovedsagelig koncepter fra årene 1723-28 indbundet i et papbind med tre blade forrest, hvorpå der er noteret, hvilke officerer der havde vagterne ved Coyets arrest 1723-24)].

2. Gustavi Cojets otia Carceralia Ao 1723 et initio Anno 1724 bestehend in allerhand Miscellaneis in 4to sub No.2 [Synes ikke bevaret, men hertil kan have hørt Ledreborg 64 4to, 42 sider, der åbenbart er udtaget fra deres sammenhæng og omhandler Karl X Gustav, dronning Kristina og lidt om Gustav Carlsson].

3. Poetæ cujuscunque Linguæ, item Satyrici, Comici et Tragici, de Ao 1724 et seqq. in 4to sub No. 3 [= Ledreborg 575 I 4to, med samme titel og nummer på omslaget. Her bl.a. om Holberg].

4. Autores Militares, Navigatorii, Fortificatorii, Pyrotechnico Artigleristæ, Strategici sub No. 4 [= Ledreborg 3474 to, med samme titel og nummer på omslaget, men kun bestående af nogle få blade vedr. „Autores Militares"].

5. Historici, Jurispublicistæ et Politici, ut et Politici Morales. Conf. Titul. Geographicorum et Itinerariorum. Item Oeconomicæ Publicæ Scriptores. Genealogici, Heraldici, Chronologici etc. ut et Numismatici et Antiquarii in 4to sub No. 5 [Tabt?].

6. Ad Stylum præprimis Gallicum et Latinum, ut et ad Poesin diversarum Linguarum pertinentia: adduntur nonnulla alia ejusdem generis, ut et ænigmata, Proverbia, Emblemata etc. etc. in 4to sub No. 6 [Tabt?].

7. Theologi et Dogmatici et Practici, ut et Morales Practici. Item Historici Ecclesiastici etc. Biblia, Commentarii Biblici, Philologi sacri, Polemici etc. in 4to sub No. 7 [Efter indholdet at dømme til dels = en tyk samling løse læg skrevet med Coyets hånd, men uden det oprindelige omslag, i NkS 592 4to. Her bl.a. om munera publica og Joh. Lassenius].

8. Ephemerides omnis generis et omnium Linguarum tum Politici quum Literarii, ut et mixti. Item 
Autores Historiæ et rei Literariæ, Scriptores vitarum Virorum eruditorum etc. ut et autores qui judicia de Libris scripserunt, cujuscunque Generis et Linguæ in 4to sub No. 8 [Efter indholdet at dømme muligvis = Hefte skrevet med Coyets hånd, men uden det oprindelige omslag, i Ledreborg, ikke registreret pakke $n$ r. 4, med optegnelser under alfabetisk ordnede stikord begyndende med 'Antiquitas'. Her bl.a. om Sylv. du Four og femmes savantes].

9. Historica et Politica in 4to sub No. 9 [= Ledreborg 353 4to, med samme titel og nummer på omslaget. Her bl.a. erindring fra Leipzig og talberegninger vedrørende Ludvig 14.].

10. Geographi et Itineraria in 4to sub No. 10 [= Ledreborg 351 4to, med samme titel og nummer på omslaget].

11. Historici Miscellanei, Livres des bons mots. Fabulæ Ramanenses et Libri amatorii. NB. exceptis Poesis in specie. in 4to sub No. 11 [= Ledreborg 346 4to, med samme titel og nummer på omslaget. Her bl.a. om ana-litteratur].

12. Theologica et Moralia in 4to sub No. 12 [Tabt?].

13. Philosophi, Logici, Metaphysici, Pnevmatici etc. etc. in 4to sub No. 13 [= Ledreborg 349 4to, med samme titel og nummer på omslaget, men kun bestående af nogle læg med et indhold svarende til indholdsangivelsen 'Philosophi' og altså ufuldstændigt. Her om Thomasius og Chr. Wolff].

14. Juris Naturalis et Gentium, Civilis, Canonici, Feudalis, Ecclesiatici etc. Scriptores in 4to sub No. 14 [= Ledreborg 573 III 4to, med samme titel og nummer på omslaget. Her bl.a. om eunukker].

15. Oratores, Grammatici et Lexicographi in quavis Lingua, ut et Lexicographi universales et particulares, item Phraseologici, elegantiarum et formularum Autores in 4to sub No. 15 [= Ledreborg 575 II 4to, med samme titel og nummer på omslaget. Her bl.a. om Pepliers grammatik].

16. Mathematici, Astrologi, Artis divinatoriæ autores, Chiromantici, Geomantici, Geometrici, Astronomi, Oncirocritici etc. Arithmetici, optici artificiosi etc. in 4to sub no. 16 [ = Ledreborg 348 4to, med samme titel og nummer på omslaget, men kun vedr. de tre første emnegrupper. Her bl.a. om Englischer Wahrsager].

17. Libri Medici, Botanici, Oeconomici, Hortulani, Physici etc. Chemici, Chirurgi, Anatomici etc. in 4to sub No. 17 [= Hefte i Ledreborg, ikke registreret pakke nr. 3, med samme titel og nummer på omslaget. Her bl.a. om kopper og de annis climactericis.

Obige Manuscripta sind insgesambt ohne No. 1 vom Verstorbenen General Major Cojet also rubricirt gewesen und von der Commission von No. 1 biss 17 numerirt worden - pro vero Extracto subsc[ripsit] J.P. Röder, Guarn[isons] Audit[ør].

[Tilføjet:] 18. Noch et Memorial til Kongen. Salutum Potationes. Medica probata. Dr. Edners Extract [De tre sidste stykker åbenbart nogle recepter. - Tabt?].

Hertil et supplement $i$ Ledreborg 265 fol.:

11 Stück Calender in 4to, so ebenfals von gedachten Gen. Major Coyet herkommen; aber nicht mit auf der specifikation stehen. Sie sind von 1700-1721, und in allen ist veschiedenes von Coyet geschrieben [Tabt?].

[Vedrørende fængselsopholdet er benyttet Victor Krohn: Kastellet Frederikshavns Fangselshistorie gennem 250 Aar, 1926, s. 47-49, Andreas Hojer: König Friedrich des Vierten glorwürdigstes Leben II, Tønder 1829, s. 101, og et samtidigt notat på omslaget af Ledreborg 454 to. - Auktionskatalogen over Coyets fængselsefterladenskaber (kun 2 blade) findes i bibliotekets Danske Afdeling, kat. 41 II-199 4to, Christian VIs udtalelse om Coyets profeti i Holger Rørdam: Historiske Samlinger og Studier III, 1898, s. 201]. 